\title{
Analisis Faktor Penentu Financial Distress Pada Perusahaan Jasa Yang Terdaftar Di Bei
}

\author{
Eny Kusumawati ${ }^{1}$, Alfina Shinta Dilas Chaniago ${ }^{2}$ \\ Universitas Muhammadiyah Surakarta ${ }^{1}$, Universitas Muhammadiyah Surakarta ${ }^{2}$ \\ e-mail: ${ }^{1}$ Eny.Kusumawati@ums.ac.id, ${ }^{2}$ alfinaschaniago@gmail.com
}

\begin{abstract}
Abstrak: Penelitian ini bertujuan untuk menganalisis faktor penentu terjadinya financial distress dengan analisis Model Altman Z-Score pada perusahaan sektor perdagangan, jasa dan investasi yang terdaftar di Bursa Efek Indonesia periode 2014-2019. Penelitian ini menganalisis pengaruh variabel profitabilitas yang diproksikan dengan return on assets (ROA). Likuiditas yang diwakili oleh current ratio (CR). Solvabilitas (leverage) yang diproksikan dengan debt equity ratio (DER). Komite audit yang diproksikan dengan jumlah komite audit. Kepemilikan institusional diproksikan dengan kepemilikan saham perusahan oleh institusi-institusi dari seluruh saham yang beredar. Metode pengambilan sampel dalam penelitian ini adalah purposive sampling. Jumlah sampel dalam penelitian ini sebanyak 50 sampel. Data rasio keuangan perusahaan pada tahun 2014-2018, kemudian digunakan unutk memprediksikan financial distress pada tahun 2015-2019. Financial distress diperoleh oleh Z-Score. Metode yang digunakan untuk pengumpulan data dalam penelitian ini adalah metode dokumentasi. Teknik analisis dilakukan dengan statistik deskriptif dan uji asumsi klasik serta uji hipotesis menggunakan metode regresi linier berganda, uji Adjusted R2, uji $\mathrm{F}$ dan uji t. Hasil penelitian menunjukkan bahwa profitabilitas, likuiditas, solvabilitas (leverage) dan kepemilikan institusional berpengaruh signifikan terhadap financial distress. Sementara itu, komite audit tidak berpengaruh terhadap financial distress.

Kata kunci: Profitabilitas, Likuiditas, Solvabilitas (leverage), Komite Audit, Kepemilikan Institusional, Financial Distress
\end{abstract}

Perkembangan ekonomi tidak lepas dari kondisi investasi di suatu negara yang berkaitan erat dengan pasar modal. Dengan adanya pasar modal, memungkinkan suatu perusahaan lebih mudah memperoleh dana dan menghimpun dana dan bagi para pemodal akan memberikan alternatif tambahan untuk menginvestasikan dana yang mereka miliki. Investasi dana nantinya akan menambah modal suatu perusahaan sehingga perusahaan mampu untuk mencapai tujuan perusahaan. Namun, dalam praktiknya seringkali perusahaan yang telah beroperasi dalam jangka waktu tertentu terpaksa bubar karena mengalami kesulitan keuangan atau financial distress.

Oleh karena itu, penting untuk melakukan analisis dan prediksi financial distress perusahaan. Platt dan Platt (2002), menyatakan bahwa financial distress didefinisikan sebagai tahap penurunan kondisi keuangan yang terjadi sebelum kebangkrutan ataupun likuidasi. Brigham dan Daves (2003), kesulitan keuangan terjadi atas serangkaian kesalahan, pengambilan keputusan yang kurang tepat dan kelemahan-kelemahan yang saling berhubungan yang dapat menyumbang secara langsung maupun tidak langsung kepada manajemen serta kurangnya upaya pengawasan kondisi keuangan perusahaan sehingga dalam penggunaannya kurang sesuai dengan apa yang dibutuhkan. 
Salah satu hal yang berpengaruh terhadap financial distress adalah financial ratios, dimana bisa dilihat di dalam laporan keuangan yang diterbitkan oleh perusahaan. Hal tersebut diperkuat dengan hasil penelitian yang telah dilakukan oleh Altman (1968), dalam penelitiannya tersebut menunjukkan bahwa rasio keuangan dapat bermanfaat untuk memprediksi kegagalan atau kebangkrutan suatu perusahaan dengan tingkat ketepatan prediksi kebangkrutan sebesar 94\% dan 95\% benar dalam penelitiannya. Model Altman ini dikenal dengan Z-Score, yaitu score yang ditentukan dari hitungan standar kali nisbah-nisbah keuangan yang menunjukkan tingkat kemungkinan kebangkrutan suatu perusahaan. Terdapat berbagai macam jenis kinerja keuangan yang digunakan sebagai prediktor kondisi financial distress perusahaan diantaranya adalah kinerja profitabilitas, likuiditas, leverage, komite audit dan kepemilikan institusional.

Penelitian ini menggunakan pengukuran model Altman Z-Score dimana model ini yang paling banyak digunakan dalam memprediksi financial distress. Sedangkan variabel independen yang akan digunakan pada penelitian ini adalah rasio profitabilitas, rasio likuiditas, rasio solvabilitas (leverage), komite audit dan kepemilikan institusional. Oleh karena itu penulis melakukan penelitian kembali tentang rasio keuangan dan Good Corporate Governance terhadap financial distress pada perusahaan jasa selama periode 2014 sampai dengan tahun 2019 dengan judul "Pengaruh Faktor Penentu Financial Distress Pada Perusahaan Jasa Yang Terdaftar Di BEl".

\section{METODE}

Jenis penelitian yang digunakan dalam penelitian ini adalah kuantitatif. Populasi dalam penelitian ini adalah seluruh perusahaan jasa yang terdaftar di Bursa Efek Indonesia selama periode 2014-2019. Jenis data yang digunakan dalam penelitian ini adalah data sekunder yang diperoleh dari website www.sahamok.com serta website masing-masing perusahaan. Sampel dalam penelitian yaitu perusahaan perdagangan, jasa dan investasi yang terdaftar di BEI sebanyak 164 perusahaan dalam satu periode. Metode pengambilan sampel yang digunakan adalah purposive sampling. Kriteria dalam pemilihan sampel dijelaskan pada Tabel 1:

Tabel 1. Data Sampel Penelitian

\begin{tabular}{|c|l|c|}
\hline No & \multicolumn{1}{|c|}{ Kriteria } & Jumlah \\
\hline 1 & $\begin{array}{l}\text { Perusahaan sektor perdagangan, jasa, dan } \\
\text { investasi yang terdaftar di BEl periode 2014- } \\
2018\end{array}$ & 164 \\
\hline 2 & $\begin{array}{l}\text { Perusahaan yang mempublikasikan laporan } \\
\text { keuangan dalam website perusahaan atau } \\
\text { pada website Bursa Efek Indonesia selama } \\
\text { periode 2014-2018 }\end{array}$ & -60 \\
\hline
\end{tabular}




\begin{tabular}{|c|l|c|}
\hline 3 & $\begin{array}{l}\text { Mengungkapkan data-data yang berkaitan } \\
\text { dengan variabel penelitian dan tersedia } \\
\text { lengkap pada publikasi selama periode } \\
2014-2018\end{array}$ & -27 \\
\hline 4 & $\begin{array}{l}\text { Perusahaan yang menerbitkan laporan } \\
\text { keuangan dengan satuan rupiah }\end{array}$ & -27 \\
\hline Total & 50 \\
\hline Total Sampel Keseluruhan (50 x 5 ) & 250 \\
\hline Data outliers selama waktu pengolahan & 20 \\
\hline Total Sampel Penelitian & 230 \\
\hline
\end{tabular}

Sumber: Data Sekunder Diolah, 2020

Variabel dependen dalam penelitian ini adalah financial distress yang diukur dari Z-Score Model Altman. Menurut Irawan (2014: 135-137) berikut formula Altman Z-Score:

$$
Z=1,2 X 1+1,4 X 2+3,3 X 3+0,64 X 4+1,0 \times 5
$$

Keterangan:

$\mathrm{Z} \quad=$ Overall index

$\mathrm{X} 1=$ Working capital / Total asset

$\mathrm{X} 2=$ Retained earnings / Total asset

$\mathrm{X} 3=$ Earnings before interest and taxes / Total asset

$\mathrm{X} 4=$ Book value of equity / book value of total debt

X5 = Sales $/$ Total asset

Klasifikasi perusahaan yang bangkrut, grey area, dan tidak bangkrut didasarkan pada nilai Z-score adalah (Muslich, 2000: 60):

1. Nilai $Z<1,81$ dikategorikan perusahaan yang bangkrut.

2. Nilai $1,81<Z<2,99$ dikategorikan dalam grey area, perusahaan tersebut tidak dapat dikatakan bangkrut tapi juga tidak dapat dikatakan sehat.

3. Nilai $Z<2,99$ dikategorikan perusahaan yang tidak bangkrut.

Sedangkan variabel independen dalam penelitian ini adalah profitabilitas yang diproksikan dengan return on asset (ROA), likuiditas yang diproksikan dengan current ratio (CR), solvabilitas (leverage) yang diproksikan dengan debt equity ratio (DER), komite audit yan diproksikan dengan jumlah anggota komite audit perusahaan, dan kepemilikan institusional diproksikan dengan dengan kepemilikan saham perusahan oleh institusi-institusi dari seluruh saham yang beredar.

\section{HASIL}

Dalam peneltian ini, data rasio keuangan perusahaan pada tahun 2014-2018, kemudian digunakan untuk memprediksikan financial distress pada tahun 2015-2019. Penelitian ini menggunakan periode pelaporan keuangan selama 5 tahun untuk memprediksi financial distress yang terjadi pada perusahaan sampel. Dengan ketentuan yang telah ditetapkan sebelumnya, diperoleh kondisi financial distress sebagai berikut:

Tabel 2. Kondisi Financial Distress Perusahaan

\begin{tabular}{|c|c|c|}
\hline Kriteria & Jumlah & Persentase \\
\hline
\end{tabular}




\begin{tabular}{|l|c|c|}
\hline & Emiten & \\
\hline Non Financial Distress & 96 & 38,4 \\
Financial Distress & 77 & 30,8 \\
Grey Area & 77 & 30,8 \\
\hline \multicolumn{1}{|c|}{ Jumlah } & 250 & 100 \\
\hline
\end{tabular}

Sumber: Data sekunder yang diolah,2020

Hasil statistik deskriptif dari variabel penelitian dapat dilihat pada tabel dibawah ini

Tabel 3. Statistik Deskriptif

Descriptive Statistics

\begin{tabular}{|l|c|c|r|r|r|}
\hline & $\mathbf{N}$ & $\begin{array}{c}\text { Minimu } \\
\mathbf{m}\end{array}$ & $\begin{array}{c}\text { Maximu } \\
\mathbf{m}\end{array}$ & $\begin{array}{c}\text { Mean } \\
\text { Deviation }\end{array}$ \\
\hline ZSC & 230 & -1.38713 & $\begin{array}{r}12.9060 \\
6\end{array}$ & 2.810500 & 1.727382 \\
& 9 & 19 \\
\hline ROA & 230 & -.22911 & .41567 & .0559509 & .0782317 \\
& & & & 6 \\
\hline CRA & 230 & .28352 & 8.44517 & 2.090826 & 1.471032 \\
2 & 59 \\
\hline DER & 230 & .01284 & 3.65403 & 1.014164 & .7321564 \\
& 230 & 2 & 4 & 3.04 & .277 \\
\hline KOA & 2304 \\
\hline KEl & 230 & .09845 & .98454 & .6559495 & .2097889 \\
& & & & 9 \\
\hline $\begin{array}{l}\text { Valid N } \\
\text { (listwise) }\end{array}$ & 230 & & & & \\
\hline
\end{tabular}

Sumber: Data Sekunder Diolah, 2020

Berdasaran tabel IV. 2 hasil analisis deskriptif maka dapat diinterpretasikan bahwa variabel dependen yaitu financial distress memiliki nilai minimum sebesar -1.38713 dengan nilai maksimum sebesar 12.90606. Nilai mean (rata-rata) pada variabel financial distress sebesar 2.8105009 hal ini menunjukkan bahwa rata-rata perusahan perdagangan, jasa dan investasi yang terdaftar di Bursa Efek Indonesia periode 20152019 melakukan prediksi financial distress sebesar $281 \%$.

Profitabilitas memiliki nilai minimum sebesar -0.22911 dan nilai maksimum sebesar 0.41567 dengan standar deviasi 0.07823176 . Dengan demikian perbandingan antara laba bersih dan total aset perusahaan perdagangan, jasa dan investasi periode 2014-2019 memiliki rata-rata 0.0559509. Hal ini menunjukkan bahwa perusahaan menghasilkan tingkat profitabilitas yang baik yang mempengaruhi terjadinya financial distress akan semakin kecil.

Likuiditas mempunyai nilai minimum sebesar 0.28352 dan mempunyai nilai maksimum sebesar 8.44517 sedangkan nilai rata-rata (mean) yang dimiliki sebesar 2.0908262 dengan standar deviasi sebesar 1.47103259. Dengan demikian perbandingan antara aset lancar dengan kewajiban lancar perusahaan sektor perdagangan, jasa dan investasi 
periode 2014-2019 memiliki nilai rata-rata sebesar 2.0908262. Hal ini menunjukkan bahwa perusahaan sektor ini memiliki tingkat likuiditas yang baik yang akan berpengaruh terhadap financial distress perusahaan.

Leverage mempunyai nilai minimum sebesar 0.01284 dan mempunyai nilai maksimum sebesar 3.65403 sedangkan nilai rata-rata (mean) sebesar 1.0141642 dengan standar deviasi sebesar 0.73215641. Dengan demikian perbandingan antara total hutang dengan total ekuitas perusahaan sektor perdagangan, jasa dan investasi periode 2014-2019 memiliki nilai rata-rata sebesar 1.0141642. Hal ini menunjukkan bahwa perusahaan sektor ini memiliki tingkat debt to equity ratio yang rendah yang menunjukkan bahwa hutang atau kewajiban perusahaan lebih kecil daripada seluruh aset yang dimilikinya hal ini akan mempengaruhi financial distress perusahaan.

Komite audit mempunyai nilai minimum sebesar 2 dan mempunyai nilai maksimum sebesar 4 sedangkan nilai rata-rata (mean) sebesar 3,04 dengan standar deviasi 0.277. Dengan demikian dapat diartikan bahwa rata-rata komite audit pada perusahaan sektor perdagangan, jasa dan investasi sebesar 3,04. Hal ini dapat diartikan bahwa efektivitas komite audit akan meningkat jika ukuran komite meningkat, karena komite memiliki sumber daya lebih untuk menangani masalah-masalah yang dihadapi oleh perusahaan termasuk financial distress.

Kepemilikan institusional mempunyai nilai minimum sebesar 0.09845 dan mempunyai nilai maksimum sebesar 0.98454 sedangkan nilai rata-rata (mean) sebesar 0.6559495 dengan standar deviasi 0.20978899. Dengan demikian dapat diartikan bahwa rata-rata kepemilikan institusional pada perusahaan sektor perdagangan, jasa dan investasi sebesar 0.6559495. Hal ini dapat diartikan bahwa kepemilikan institusional pada perusahaan baik karena kepemilikan institusional yang besar (lebih dari 5\%) akan memberikan kemampuan yang lebih baik untuk memonitor manajemen termasuk financial distress perusahaan.

\section{Uji Asumsi Klasik}

Tabel 4. Hasil Uji Normalitas

\begin{tabular}{|l|c|}
\hline Keterangan & $\begin{array}{c}\text { Unstandardized } \\
\text { Residual }\end{array}$ \\
\hline Kolmogorov-Smirnov Z & 1,077 \\
Asymp. Sig. (2-tailed) & 0,196 \\
Keterangan & Normal \\
\hline
\end{tabular}

Sumber: Hasil Olah Data SPSS, 2020

Berdasarkan hasil diatas, diperoleh bahwa Asymp. Sig. (2-Tailed) menunjukkan hasil sebesar 0,196 atau $19,6 \%$ yang menandakan bahwa data telah terdistribusi normal, hal ini dikarenakan nilainya lebih besar dari 0,05 atau $5 \%$. 
Tabel 5. Hasil Uji Multikolinearitas

\begin{tabular}{|c|c|c|c|}
\hline \multirow[t]{2}{*}{ Variabel } & \multicolumn{2}{|c|}{$\begin{array}{c}\text { Uji } \\
\text { Multikolinearitas }\end{array}$} & \multirow{2}{*}{$\begin{array}{c}\text { Uji } \\
\text { Heteroskedastisit } \\
\text { as }\end{array}$} \\
\hline & $\begin{array}{c}\text { Toleranc } \\
\mathrm{e}\end{array}$ & VIF & \\
\hline \multirow{5}{*}{$\begin{array}{l}\text { Profitabilitas } \\
\text { Likuiditas } \\
\text { Solvabilitas } \\
\text { (Leverage) } \\
\text { Komite audit } \\
\text { Kepemilikan } \\
\text { institusional }\end{array}$} & 0,815 & 1,227 & 0,889 \\
\hline & 0,717 & 1,395 & 0,098 \\
\hline & 0,684 & 1,462 & 0,256 \\
\hline & 0,989 & 1,011 & 0,928 \\
\hline & 0,959 & 1,042 & 0,352 \\
\hline
\end{tabular}

Sumber: Hasil Olah Data SPSS, 2020

Berdasarkan hasil uji multikolinearitas untuk model persamaan regresi menunjukkan nilai value inflation factors (VIF) antara 1,395-1,227 (tidak lebih dari 10) dan tolerance value antara 0,815-0,717 (lebih dari 0,1) Hal ini berarti bahwa model regresi terbebas dari adanya korelasi yang tinggi antara variabel independen sehingga kesimpulannya adalah model tidak terjadi multikolinearitas

Berdasarkan tabel diatas hasil uji heterokedastisitas, semua variabel independen mempunyai nilai signifikansi lebih besar dari 0,05 atau 5\%. Sehingga dapat disimpulkan bahwa tidak ada heteroskedastisitas dalam persamaan regresi dan model regresi tersebut layak digunakan dalam penelitian ini.

Tabel 6. Hasil Uji Autokorelasi

Runs Test

\begin{tabular}{|l|r|}
\hline & $\begin{array}{c}\text { Unstandardized } \\
\text { Residual }\end{array}$ \\
\hline Test Value &,- 15315 \\
Cases $<$ Test & 115 \\
Value & 115 \\
Cases $>=$ Test & 230 \\
Value & 114 \\
\hline Total Cases &,- 264 \\
Number of Runs &, 792 \\
\hline Z & \\
\hline Asymp. Sig. (2- & tailed) \\
\hline
\end{tabular}

Sumber: Hasil Olah Data SPSS, 2020

Pada pengujian autokorelasi, peneliti menggunakan uji run test. Berdasarkan hasil pengujian diatas, nilai asymp.Sig (2-tailed) sebesar 0,792 dimana lebih besar dari 0,05 atau $5 \%$. Hal ini membuktikan bahwa tidak adanya autokorelasi. 


\section{Uji Hipotesis}

1. Uji Regresi Linier Berganda

Tabel 7. Hasil Uji Regresi Linier Berganda

\begin{tabular}{|c|c|c|c|c|}
\hline Variabel & $\begin{array}{c}\text { Coefficien } \\
\text { ts }\end{array}$ & $\mathbf{t}$ & Sig. & $\begin{array}{c}\text { Keteranga } \\
n\end{array}$ \\
\hline (Constant) & 0,576 & 0,534 & 0,594 & \\
\hline Profitabilitas & 13,928 & 10,839 & 0,000 & $\begin{array}{c}\mathrm{H} 1 \\
\text { diterima }\end{array}$ \\
\hline Likuiditas & 0,191 & 2,615 & 0,010 & $\begin{array}{c}\mathrm{H} 2 \\
\text { diterima }\end{array}$ \\
\hline $\begin{array}{l}\text { Solvabilitas } \\
\text { (leverage) }\end{array}$ & 0,633 & 4,224 & 0,000 & $\begin{array}{c}\text { H3 } \\
\text { diterima }\end{array}$ \\
\hline $\begin{array}{l}\text { Komite } \\
\text { Audit }\end{array}$ & $-0,199$ & $-0,604$ & 0,547 & H4 ditolak \\
\hline $\begin{array}{l}\text { Kepemilikan } \\
\text { Institusional }\end{array}$ & 1,555 & 3,522 & 0,001 & $\begin{array}{c}\mathrm{H} 5 \\
\text { diterima }\end{array}$ \\
\hline $\begin{array}{l}\text { Fhitung } \\
\mathrm{R}^{2} \\
\text { Adjusted } \mathrm{R}^{2}\end{array}$ & & 27,677 & $\begin{array}{r}0,000^{\mathrm{b}} \\
0,382 \\
0,368\end{array}$ & \\
\hline
\end{tabular}

Sumber: Hasil Olah Data SPSS, 2020

Berdasarkan hasil pengujian regresi berganda pada tabel 7 diatas maka diperoleh persamaan regresi linier berganda sebagai berikut:

Fin. Distress $=0,576+13,928 \mathrm{PROFIT}+0,191 \mathrm{LIKUID}+0,633 \mathrm{LEV}+-$ $0,199 \mathrm{KA}+1,555 \mathrm{KI}+\varepsilon$

Nilai konstanta menunjukkan sebesar 0,576 berarti apabila profitabilitas, likuiditas, solvabilitas (leverage), komite audit dan kepemilikan institusional konstan maka financial distress sebesar 0,576.

Koefisien regresi profitabilitas menunjukkan nilai positif sebesar 13,928 yang berarti apabila jumlah return of assets semakin bertambah dalam suatu perusahaan, maka semakin efektif perusahaan dalam mengelola aset perusahaan dan semakin kecil biaya yang dikeluarkan perusahaan kemungkinan terjadinya financial distress akan menjadi semakin kecil dan sebaliknya.

Koefisien regresi likuiditas menunjukkan nilai positif sebesar 0,191 yang berarti semakin bertambahnya current ratio suatu perusahaan, maka perusahaan mengelola hutang lancar dengan aktiva yang dimilikinya dengan baik sehingga tidak terjadi financial distress dan sebaliknya.

Koefisien regresi solvabilitas (leverage) menunjukkan nilai positif sebesar 0,633 yang berarti semakin tinggi debt to equity ratio maka akan semakin besar kemungkinan perusahaan mengalami financial distress dan sebaliknya.

Koefisien regresi komite audit menunjukkan nilai negatif sebesar 0,199 yang berarti komite audit yang memiliki anggota lebih besar akan memiliki sumber daya yang lebih untuk menangani masalah-masalah yang dihadapi oleh perusahaan seperti masalah kesulitan keuangan (financial distress) dan sebaliknya. 
Koefisien regresi kepemilikan institusional menunjukan nilai positif sebesar 1,555 yang berarti semakin besar kepemilikan institusional maka semakin efisien pemanfaatan aset perusahaan, sehingga potensi kesulitan keuangan atau financial distress dan sebaliknya.

2. Uji Ketepatan Model (F-test)

Berdasarkan hasil pada tabel 7 diatas, uji $F$ tersebut menunjukkan bahwa $\mathrm{F}$ hitung memiliki nilai sebesar 27,677 tingkat signifikansi sebesar 0,000 sehingga dengan nilai signifikansi kurang dari 0,05 dapat dikatakan fit model regression.

3. Uji Koefisien Determinasi $\left(R^{2}\right)$

Hasil uji koefisien determinasi dapat dilihat pada tabel 7. Dilihat dari nilai koefisien determinasi (Adjusted $R^{2}$ ) menunjukkan nilai sebesar 0,368 sehingga dapat diartikan bahwa variabel independen dapat menjelaskan variabel dependen sebesar 36,8\% kemudian sisanya sebesar 63,2\% dijelaskan oleh variabel lain diluar model.

\section{Uji T}

Berdasarkan tabel 7 diatas diperoleh hasil sebagai berikut, tingkat signifikansi variabel profitabilitas menunjukkan nilai sebesar 0,000 0,05 dan dapat disimpulkan bahwa profitabilitas berpengaruh terhadap financial distress. Tingkat signifikansi variabel likuiditas menunjukkan nilai sebesar $0,010<0,05$ dan dapat disimpulkan bahwa likuiditas berpengaruh terhadap financial distress. Tingkat signifikansi variabel solvabilitas (leverage) menunjukkan nilai sebesar 0,000 $<0,05$ dan dapat diperoleh kesimpulan bahwa solvabilitas (leverage) berpengaruh terhadap financial distress. Tingkat signifikansi variabel komite audit menunjukkan nilai sebesar 0,547 > 0,05 dan dapat diperoleh kesimpulan bahwa komite audit tidak berpengaruh terhadap financial distress. Tingkat signifikansi variabel kepemilikan institusional menunjukkan nilai sebesar 0,001 $<0,05$ dan diperoleh kesimpulan bahwa komite audit berpengaruh terhadap financial distress.

1. Profitabilitas berpengaruh terhadap financial distress

Hasil uji t menunjukkan hasil bahwa variabel profitabilitas berpengaruh terhadap financial distress. Profitabilitas dapat digunakan untuk mendeteksi terjadinya kesulitan keuangan dalam laporan keuangan suatu perusahaan dikarenakan kemampuan rasio ini dalam menghasilkan laba yang tinggi. Semakin besar rasio yang dihasilkan, maka semakin baik perusahaan dalam menghasilkan laba bagi perusahaan sehingga semakin terhindar dari financial distress sehingga menunjukkan semakin efektif perusahaan dalam mengelola aset perusahaan.

Hal ini disebabkan kemungkinan efektivitas dari penggunaan aset perusahaan akan mengurangi biaya yang dikeluarkan oleh perusahaan, sehingga terjadi penghematan biaya dan perusahaan memiliki kecukupan dana untuk menjalankan usahanya di periode berikutnya. Hal ini sejalan dengan penelitian yang dilakukan Imam dan 
Reva (2012), Novita R dkk (2014) menyimpulkan bahwa profitabilitas berpengaruh terhadap financial distress.

2. Likuiditas berpengaruh terhadap financial distress

Hasil uji $t$ menunjukkan hasil bahwa variabel likuiditas berpengaruh terhadap financial distress. Likuiditas dapat digunakan untuk mendeteksi adanya kesulitan keuangan (financial distress) dalam laporan keuangan suatu perusahaan dikarenakan likuiditas perusahaan yang semakin besar akan membuat perusahaan semakin dalam keadaan sehat dan semakin baik dalam hal pengelolaannya sehingga tidak terjadi financial distress.

Jika nilai rasio semakin besar maka menunjukkan lebih banyak perusahaan menggunakan utang, di mana hal ini mengindikasikan bahwa perusahaan berpotensi mengalami financial distress. Hal ini sejalan dengan penelitian yang dilakukan Hidayat dan Meirianto (2014) menyatakan bahwa likuiditas menunjukkan kemampuan perusahaan melunasi utang jangka pendeknya dan perusahaan tersebut semakin jauh dengan ancaman kesulitan keuangan (financial distress).

3. Solvabilitas (leverage) berpengaruh terhadap financial distress

Hasil uji $t$ menunjukkan hasil bahwa variabel solvabilitas (leverage) berpengaruh terhadap financial distress. Solvabilitas (leverage) dapat digunakan untuk mendeteksi adanya kesulitan keuangan (financial distress) dalam laporan keuangan suatu perusahaan dikarenakan solvabilitas menunjukkan seberapa besar aset perusahaan dibiayai dengan utang atau seberapa besar utang perusahaan berpengaruh terhadap pengelolaan aktiva.

Hal ini sejalan dengan penelitian yang dilakukan Hidayat dan Meirianto (2014), Miglani et al. (2014) dan Hartianah dan Sulasmiyati (2017) bahwa rasio leverage menunjukkan seberapa besar utang yang dimiliki oleh perusahaan (jangka pendek dan jangka panjang), Jika total utang perusahaan terlalu besar, maka akan mengakibatkan suatu perusahaan semakin rawan terhadap financial distress.

4. Komite audit tidak berpengaruh terhadap financial distress

Hasil uji t menunjukkan hasil bahwa variabel komite audit tidak berpengaruh terhadap kesulitan keuangan (financial distress). Komite audit tidak dapat mendeteksi adanya kesulitan keuangan (financial distress) dimungkinkan karena kurangnya sumber daya komite audit. Dengan ukuran komite audit yang lebih besar maka sumber daya komite audit akan meningkat dan kualitas pengawasan juga meningka sehingga memiliki sumber daya yang lebih untuk menangani masalahmasalah yang dihadapi oleh perusahaan seperti masalah kesulitan keuangan (financial distress).

Hal ini sejalan dengan penelitian yang dilakukan Radifan dan Yuyetta (2015), hubungan positif antara ukuran komite audit dengan kinerja keuangan perusahaan didukung teori ketergantungan sumber daya. Berdasarkan teori ketergantungan sumber daya, dengan 
semakin meningkatnya jumlah anggota membuat komite audit memiliki lebih banyak sumber daya khususnya untuk menghadapi masalah yang sedang dialami perusahaan..

5. Kepemilikan institusional berpengaruh terhadap financial distress

Hasil uji $\mathrm{t}$ menunjukkan hasil bahwa variabel kepemilikan institusional berpengaruh terhadap kesulitan keuangan (financial distress). Kepemilikan institusional dapat mendeteksi adanya kesulitan keuangan (financial distress) pada laporan keuangan perusahaan dikarenakan tingginya kepemilikan investor institusional akan mendorong aktivitas monitoring karena besarnya kekuatan voting mereka yang akan mempengaruhi kebijakan manajemen. Semakin besar kepemilikan institusional maka semakin efisien pemanfaatan aset perusahaan, sehingga potensi financial distress dapat diminimalkan karena perusahaan dengan kepemilikan institusional yang lebih besar (lebih dari 5\%) mengindikasikan kemampuannya untuk memonitor manajemen. Hal ini sejalan dengan penelitian yang dilakukan Bodroastuti (2009) yang menyatakan bahwa kepemilikan institusional berpengaruh kesulitan keuangan (financial distress) perusahaan.

\section{KESIMPULAN}

Berdasarkan hasil penelitian pada perusahaan perdagangan, jasa dan investasi pada tahun 2014-2019, maka kesimpulan yang dapat diambil dari penelitian ini ialah variabel independen secara simultan berpengaruh terhadap financial distress yaitu profitabilitas, likuiditas, solvabilitas (leverage), dan kepemilikan insttitusional. Sedangkan variabel komite audit tidak berpengaruh terhadap financial distress.

\section{DAFTAR PUSTAKA}

Altman, E. I. (1968). The prediction of corporate bankruptcy: A discriminant analysis. Journal of Finance, 23(1), 193-194.

Bodroastuti. 2009. Pengaruh Struktur Corporate Govenance terhadap Financial Distress. Jurnal Ekonomi Dan Bisnis.

Brigham, E. F., \& Daves, P. R. (2003). Intermediate Financial Distress Management With Thomson One. United States of America: Cengage South-Western.

Hartianah, \& Sulasmiyati. (2017). Pengaruh Aspek Operasional , Corporate Governance, Dan Makroekonomi terhadap Financial Distress Studi Pada Perusahaan Agrikultur Yang Terdaftar Di Bursa Efek Indonesia Tahun 2011-2015 ). Jurnal Administrasi Bisnis (JAB), 47(2), 65-73.

Hidayat, M. A., \& Meiranto, W. (2014). Prediksi Financial Distress Perusahaan Manufaktur Di Indonesia. Diponegoro Journal Of Accounting, 3(Issn (Online): 2337-3806), 1-11.

Imam Mas'ud dan Reva Maymi. (2012). Analisis Rasio Keuangan untuk Memprediksi Kondisi Fanancial Distress Perusahaan Manufaktur 
yang Terdaftar di BursaEfek Indonesia. Jurnal Akuntansi Universitas Jember. Vol. 10. No. 2.

Miglani, S., Ahmed, K., \& Henry, D. (2015). Voluntary Corporate Governance Structure And Financial Distress: Evidence From Australia. Journal Of Contemporary Accounting \& Economics, 11(1), 18-30.

Muslich, Mohamad. (2000). Manajemen Keuangan Modern (Analsis, Perencanaan, dan kebijaksanaan). Bumi Aksara: Jakarta.

Parahita Irawan. (2014). Street Investing Redevelop The Ideas. CM Press.

Platt, Harlan D. Dan Marjorie B. Platt. (2002). Predicting Corporate Financial Distress: Reflection on Ccoice-Based Sample Bias. Journal of Economic and Finance 26. Summer: 184-199.

Rahmadani, Novita. (2014). Analisis Pengaruh Rasio Likuiditas, Profitabilitas, Rentabilitas Ekonomi dan Laverage Terhadap Prediksi Financial Distress (Studi Kasus Pada Sektor Perbankan Di Bursa Efek Indonesia Periode 2009- 2013). Skripsi. Universitas Pendidikan Ganesha, Singaraja.

Radifan, R., \& Yuyetta, E. N. A. (2015). Analisis Pengaruh Mekanisme Good Corporate Governance terhadap Kemungkinan Financial Distress (Doctoral dissertation, Fakultas Ekonomika dan Bisnis). 